\title{
British colonialism in East-Africa during nineteenth century
}

\author{
Nazifa Rashid \\ Department of History, University of Chittagong, Bangladesh.
}

\begin{abstract}
Colonialism prevailed in Asia and Africa; in America there was colonialism. It was Great Britain which championed colonialism to an intense degree. Other European countries too had their colonies. After each colony attained independence, it so happened that colonialism was not rooted out, but a new type of colonialism persisted and manifested its primordial characteristics. My main objective is that British colonialism in East-Africa during $19^{\text {th }}$ century's; which was very much important for the economical causes like slave trade, various spices trade, etc. There are only few studies on the colonial history of British-east Africa. This article contains-how and why British interested there and its effect. It has also described their administrative system at that time.
\end{abstract}

Colonialism is the establishment, exploitation, maintenance, and expansion of colonies in the territory by people from another territory. It is a set of unequal relationships between the colonial power and the colony and often between the colonists and the indigenous population. This idea, mainly, came from the west. Marx said about it-"Colonialism presented capitalism in naked form, stripped of decorous, clothing of European bourgeois society (Marx 1973; 324)”. Colonialism ,Sartre was to add ,also operates in a different temporality from Western capitalism, in the time of its secondary system ,Fanon in turn would point to differs of temporality within the colonial domain , 'a time lag' between the cosmopolitan modernity of the nationalists leader and peasantry. However, 'British Colonialism in east Africa during nineteenth century' is our main topic, which I have described in short briefing.

At present time, territorial East-Africa means Kenya, Tanzania, (Tanganyika, and Zaire) and Ugandathese three countries. There were few and famous islands like Zanzibar, Mozambique, Mafia, Kilwa, Mombasa, Malindi, and Pemba etc. in East-African region. Analyses the East-Africa in geographically ,Somali desert and Ethiopian mountain range in its northern side, large lakes in its western side(Albert, Kivu, Tanganyika Nyasa etc.); Zambezi in south and Indian Ocean in east. This territory is about one million square mile .It is a densely populated area and apparently it looks like a plateau. This area was very important for European countries during nineteenth century especially Britain. So they colonized East-Africa and many other parts of Africa .During the eighteenth century European empires in America reached their peak, and the foundations of European power were laid in the east. But in Africa there was little evidence of European activities. This is at first sight surprising, for the earliest European overseas expansion took place in north-west and West-Africa .During the fifteenth century the Portuguese established on the west coast at Arguin, Elmina ,Sao Tome ,and San Salvador ; their discovery of the cape of good hope in 1487 ked to occupation of main existing ports of east Africa-Sofala ,Mozambique , and others, extending as far as Red sea and Ormuz .During the sixteenth century it seemed possible that Portugal might establish territorial colonies in the Congo region ,Angola and the Zambezi ,where adventurers and missionaries were following the same paths as conquistadores and religious orders in Spanish America. But gradually these enterprises withered. The Portuguese Crown lost interests in exploration and conversion; India and the east monopolized its energies; Africa was seen either as an obstacle on the route to the Indies or as a source of gold dust and ivory and to slaves for the American plantations. Portugal showed no desire or capacity to develop its coastal bases into colonies .In due course other European countries adopted Portuguese attitudes and practices. The Portuguese and Arabs controlled all the ports of east Africa. The trade was run by Portuguese firms which bought a monopoly of rights for defined periods and paid a duty on slaves brought some wealth to Angolan ports ,but slaving was incompatible with territorial empire and created an wilderness in east African ports specially Tanganyika, Zanzibar etc. During the seventeenth century, the Dutch attacked shipping and seized the Indian and eastern bases whose trade had previously brought wealth to Portuguese East Africa. Arabs were expanding from the north and captured all ports north of Zanzibar. Inland the empire had broken the power of the Monomatapas, the allies of Portugal, and weakened her influence south of the Zambezi. Mozambique remained the Portuguese capital.

Portuguese power in Africa was waning during the eighteenth century: that of Britain was surprisingly increasing. From the start the British thought of Africa as a source of slaves for America and an obstacle on the route of India. They established no proper colonies, and left private companies to run the slave trade. Rent had to be paid to local African rulers. The supply of slaves was irregular , and African middlemen, who had a monopoly of supplying a fixed market, used it to force up the price. It is necessary to say that company servants 
were unreliable and corrupt. Nearly two centuries British activities on the West and East Africa had produced no significant expansion of territory or influence .But by 1815 , British had made genuine colonies in there, which were not slaving centers. Because they would eventually be given up the slave trade in 1807 .Besides this, in 1758 a strong British naval expedition captured all French bases in West-Africa after their war. But east Africa which was controlled by Muslims; Arabs were building an impressive slave trading empire in there. When the European countries to close the slave trade, the British would remain there; but their reasons for doing so were now different. Suppression of slaving was primary; the development of a legitimate commerce came second. Together these provided the roots from which British most activities in West-Africa grew during the next sixty years. By 1815, however, the British-empire had enlarged up to the East-Africa. Legitimate trade also existed in 1815; but it was so small that it did not yet constitute a major incentive for European expansion into Africa.

When the British decided to come into the east Africa especially in Mozambique, Portuguese were too weak to extend their territory in there. Mozambique was very important for trade in groundnuts and palm oil. But for long it was relatively small in vale and these goods were supplied by the African middlemen, the trade itself was necessarily an incentive for colonization. So they were not interested expanding their colonies at that time. That was the time of growth of European power in Africa.

It is easy to say that, after 1815 Portugal retained only the island of Mozambique, a few coastal forts, and the virtually independent prazos (feudal principalities) up the Zambezi. The modern history of Portugal overseas hinges on the 1880s. Until then her empire appeared to be decadent from the 1580s until 1822 one colony after another was lost. On the other hand, most of the East-Africa was controlled by Muslim sultans. In there, the roots of European expansion were the financial weakness of debtor sultans and the reaction of Islamic nationalists to alien encroachments. But none collapsed through financial insolvency in this period. European investments were spiritual and geographical rather than financial.

Table-1: The Formal British Empire in East-Africa, 1893

\begin{tabular}{|l|l|l|l|l|l|}
\hline Territory & $\begin{array}{l}\text { Area } \\
\text { miles) }\end{array}$ & Estimated Population & Number of Europeans & Value of exports (£) & $\begin{array}{l}\text { Form } \\
\text { government }\end{array}$ \\
\hline $\begin{array}{l}\text { British East } \\
\text { Africa } \\
\text { protectorate } \\
\text { (including } \\
\text { Uganda) }\end{array}$ & c.340,000 & c. $4,000,000 ?$ & c. 200 & 86 & $\begin{array}{l}\text { Chartered } \\
\text { Company }\end{array}$ \\
\hline Zanzibar & 1,000 & & & & \\
\hline
\end{tabular}

SOURCE: The Statesman's Yearbook, 1894

In East-Africa Britain's trade was considerably less than on the west coast, and its East African commerce gave much less scope to small peasant cultivators. Principal British imports centered on luxury goods, including ivory a commodity obtained through the skills of professional hunters; sugar, grown mainly on Mauritian, plantations; and cloves, derived from Arab owned estates on the island of Zanzibar. British political influence in the sultanate of Zanzibar depended on a partnership with a local Islamic oligarchy of great estate owners and merchants. But in Zanzibar, as at Constantinople, British policy rested on unresolved contradictions. On the one hand Britain wanted to enforce reforms acceptable to the British humanitarian conscience; these reforms hinged on free trade, free wage labor, and the benevolent treatment of the weak. On the other hand the home government wanted to avoid expensive commitments, and therefore, looked to traditional rulers to carry out reforms that were incompatible with traditional instructions.

In East-Africa the British were determined to wipe out the Muslim slave trade one of the props sustaining the social system of Zanzibar. This obliged them to play an ever increasing role in the affairs of the sultanate. At the same time British Indian financiers and business men acquired growing influence within the island's economy. In 1869 Suez Canal was opened, and western European ships bound for India could avoid the long haul around the cape. Four years later the British-relying on their overwhelming sea power succeeded in closing the Zanzibar slave markets, with the result that the sultan become over more dependent on royal navy support. During the 1870s, therefore British power engaged in many parts of East-Africa. It was also the time of industrial revolution in the European countries; the British had needed a wide market for trade. Thus, the British had chosen the East-African coasts.

In East Africa, the period 1885-90 was more decisive, because British and Germany able to come to satisfactory agreements with little difficulty, which was called 'Scramble of Africa'. Italy had acquired Assab, on the red sea, and wanted to build on empire for prestige reasons in the horn of Africa. She was weak, but she was a member of triple alliance, and this entitled her to German sympathy and stimulated Britain offer counter bribes. Bismarck had little interest in East-Africa, beyond the welfare of Carl peters' East-African company. Bismarck supported him in whatever treaties he made with Africans to extend his company's claims provided these did not procedure a serious quarrel with Britain. Britain, in fact, had the greatest stake in East-Africa; but her interests were typical of the involutes diplomacy of position. There were British missions in Uganda, and the 
Scottish ship owners, William Mackinnon, was trying to establish a trading empire between Mombasa and Lake Victoria, including control of the inland possessions of the Arab Sultan of Zanzibar. Mackinnon was given a charter for his imperial British East-Africa company to enable him to complete with peters in treaty making: but in fact British statesmen regarded both missions and company as expendable. The vital British interest east India. German control of the coast would endanger the first; German or other control of Uganda or the upper Nile would treat Egypt and the Suez Canal. Ironically, therefore, British statesmen felt bound to stake more on East-Africa, the least attractive of all colonial lots at auction, than in other places where real bargains were to be had. Until 1898 this fact dominated the diplomacy of partition.

The key dates were 1886 and 1890. In 1886 lord Salisbury forestalled possible German claims to Uganda by recognizing the German protectorate over Dar-Es-Salam and Pangani, and by implication also Witu and the coast fronting in return for a provisional British sphere of influence north of a line from Wonga to Lake Victoria. Zanzibar which was under British control and become a full protectorate in 1890 was to control a long stretch of coast to the depth of ten miles. By 1890 Salisbury was clear that the Britain would remain in Egypt independently. This made control of Uganda fundamental and a more definite division was made by the socalled Mozambique to Lake Nyasa, Lake Tanganyika and the boundary of the Congo Free State west of Lake Victoria, but stopping short of Uganda. Germany was given Helgoland, Helgoland treaty. Britain recognized a German protectorate running from Portuguese, which most German thought a better acquisition than Uganda. In return Germany recognized a British sphere of influence stretching north without a break from the previous demarcation line, and also the British protectorate over Zanzibar.

This 1890 treaty virtually fixed the pattern of colonial East-Africa. It remained to decide whether Britain would convert her sphere of influence into a formal protectorate or colony or merely keep Germany out of it; what boundaries would be drawn between Uganda Congo Free State; whether the Congo would cede a corridor west of Lake Tanganyika, so that Uganda and Egypt could be linked with Central Africa; and finally whether France or Italy would dispute British predominance in the Egyptian Sudan.

Thus Britain established her protectorate over East-Africa step by step. Its administrative system was also running strongly day by day. According to the Marxist interpretation of history, the colonial system was a capitalist invention designed to enrich merchants and industrialists, they were supposed to have sent their sons out to rule the empire. Or conversely, the rulers of the empire were but the employees of moneymen, chosen to serve the wealthy. In fact, British colonial governors rarely had any links with the instruments of production or finance.

By the end of nineteenth century, the British colonial system fell into three categories; firstly, the crown colonies, under the aegis of the colonial office; secondly the protectorates, most still at this point under the foreign office and the chartered company, also theoretically under the colonial office but only loosely supervised at best. Most of the men, who governed the colonies, were called governor. In East-Africa, as we have seen, the leading exponent of chartered enterprise and railway investment was William Mackinnon, who combined his evangelical fervor and British patriotism with a bitter hatred of Germany. His chosen instrument was the imperial British East-African company, like the royal Niger Company, a trading firm. It received its royal charter in 1889. AS John S. Galbraith, Mackinnon's bio-graphic, has noted, the subscriber represented the upper riches of Anglo-Scottish society. Business interests, philanthropy, independent wealth and distinguished public service were blended into a governing board with East-African interests; it could command respect from any government, liberal or tray. For board members were themselves MPs. The former grocer's clerk had risen in society and become a power in the land.

The Imperial British East-African company, however, proved an economic failure and surrendered its charter in 1895. East-Africa laked an easily accessible source of wealth, and the enterprise had began with an inadequate economic base. The company could not complete in trade with Indian merchant from the coast; the income from custom revenue was inadequate to support even a rudimentary form of western government; agriculture development was impossible without railway construction that the company, with its limited resources, could not afford. When the Imperial East-African Company was failure, the company lost its charter. After the company's administration, perhaps 10 percent of officials in the administration of British East-Africa before 1914 had come from South African Nyasaland or Rhodesia. The company's administrative organization was, in fact, slender. It was run by a council in London and directed operations in East-Africa through an agent general, three provincial and some district superintendents. The company mentioned a small military police force, consisting of Hausa and Yoruba; it owned a small and lightly armed river fleet and a battalion. Real power rested with company administration, Mackinnon. Finally we have seen company administrative system in East-Africa in some ways those of West Africa.

After 1895 there were some changes in the British administration in East-Africa. Queen Victoria was very interested in colonial affairs and wanted to see all important dispatches. She looks an active interest in the appointment of governors, being anxious to keep them independent of parliament and political parties. Some bore different titles at various times and in various parts of the empire- Zanzibar a resident, Swaziland a resident 
commissioners, and Uganda a commissioner- but they were governor all the same, which is two say chief executives, responsible for the day to day administration of their territories.

However, East-African region was ruled by a governor after 1895. It is necessary to say that the governor's duties were both formal and informal; they were written down in various rules and regulations and developed through his relations with the colonial office. He was appointed by the sovereign on the recommendation of the colonial secretary after consultations with the prime minister. He acted as the sovereign's representative. As head of the executive, he supervised the work of all departments and scrutinized all matters of importance. In a word, the governor was all in all in his region. Besides these, chief justice, colonial secretary, colonial treasurer and colonial surgeon like teacher school officials etc. were in administrative bodies. The local administration also supplied the governor with an impressive domestic staff, a major domo, stewards, chiefs, chauffeurs, house boys, gardeners and laundrymen- sometimes as many as so people.

The end of the nineteenth century, the East-Africa was ruled by governor sir Charles Eliot and Alfred Claud Hollis (Sir Claud) was personal secretary to Sir Eliot. Hollis made everything running smoothly in there. In 1887, at the age of twenty three, he joined the administration as district commissioner. In 1902, he took direction of the newly formed secretariat in British East-Africa and proved to be a capable administrator. By 1912, he was a resident of Zanzibar and would up as governor of Trinidad and Tobago. He did well everything, especially he wrote widely on anthropology and allied subjects, including books on the Nandi and the Masai. He sided with the "negrophilists".

The British dominated the East-Africa in the nineteenth century-religion, race, class and nationality. The British, in their own estimation, had created the world's most successful society prosperous by comparison with most of their neighbors, law-abiding and stable, secure from foreign invasion. These values were reflected in British attitudes towards the Africans, Specially, the changes were in African society. Mistakenly or not, the bulk of British administrators were convinced that colonialism was an instrument of social reform.

In East-Africa, the impact of British protectorate was not only absorbed but also effective; Example, the railway, the telegraph, many hospitals, schools, were founded there. The most important results of British activity apart from where, in fact, the introduction of new food stuffs, notably cassava, maize and sweet potatoes, which greatly improved African diets. Besides this, the British had made a little more than beginning in spreading their language, their nations concerning government and their religion in Africa. The British activity also made African nationalists movements in the twentieth century.

At last, we have seen, in East-Africa, the British came as colonizers, indeed they prided themselves on that role. This is not an easy task. Few words arouse as much hostility in the modern world as the word colonialism. Colonialism-the argument goes accounts for much of the wealth accumulated by the rich nations of world at the expanse of the poor. Colonialism, moreover, must bear the blame not merely for the property, but also for the stagnation of the so-called under developed world like East-Africa.

\section{References}

[1] African History-Philip curtain, Steven Feirman, Leonard Thompson and Jan Vansina

[2] The rule of German Africa (1884-1914) - L. H. Gann \& Peter Duignan

[3] Common Sense about Africa-Antony Sampson

[4] Tanzania-An African Experiment- Rodger Yeager

[5] The Rulers of British Africa- L. H. Gann \& Peter Duignan

[6] The Colonial Empires - A Comparative Survey from the Eighteenth Century - D. K. Fieldhouse 